\title{
Studies on Diagnosis and Repair for Reinforcing Bar Corrosion by Salt Injury
}

\author{
Hidenobu TATEMATSU, Dr.Eng. \\ General Manager, \\ Planning Div.
}

Takahiko SASAKI

Laboratory Head,

Inorganic Material, Materials Technology Div.
Tooru IIJIMA

Assistant Senior Researcher,

Reinforcing bar corrosion by salt injury (or salt damage) is a most serious problem that threatens the durability and strength of a concrete structure. It was clarified that the half-cell potential could be influenced by some properties of cover concrete, and a half-cell potential correction procedure taking the properties of cover concrete into account was proposed. Then, to suppress the reinforcing bar corrosion caused by salt injury, an anion adsorbent was chemically synthesized which could adsorb excess amounts of chlorine ions, releasing nitrous ions at the same time. Using materials containing this adsorbent, we propose a new repair method named Suppressing Salt Injury method (SSI method).

Keywords : reinforcing bar, salt injury, diagnosis, half-cell potential, anion adsorbent, chlorine ion, nitrous ion, repair

\section{Introduction}

Extensive research ${ }^{1)-3)}$ is being promoted on the diagnosis and countermeasures for reinforcing bar corrosion caused by salt injury because such corrosion seriously damages the durability and strength of concrete structures. To diagnose reinforcing bar corrosion, non-destructive methods are being studied from the viewpoint of utilizing electrochemical characteristics ${ }^{4) 5}$. Among them, the half-cell potential method $^{6)}$ is the most popular because of its easy operation. The half-cell potential measured at a concrete surface is influenced by the properties of cover concrete. As a result, the actual state of corrosion can not always be evaluated correctly by the half-cell potential method. To protect concrete structures from salt injury, concrete surfaces are wholly treated with water-impenetrable materials to prevent the penetration of salt and water from the outside. Such treatments can be performed easily at relatively low cost. Even after treatments, however, the salt in concrete remains inside, and the water content often increases and accelerates the deterioration of concrete. To completely suppress the salt injury, it is desirable to extract salt from concrete as much as possible.

In this study, first of all, we re-examined the half-cell potential method, which has been generally applied for diagnosis of the reinforcing bar corrosion. It was clarified that the reliability of the half-cell potential method could be improved if the half-cell potential was be suitably corrected for the water content and the carbonation depth. Such a half-cell potential correction procedure was proposed. Second, we chemically synthesized an adsorbent that could adsorb chlorine ions $\left(\mathrm{Cl}^{-}\right)$and release nitrous ions $\left(\mathrm{NO}_{2}^{-}\right)$which could suppress reinforcing bar corrosion, and developed the Suppressing Salt Injury method (SSI method) by using repairing materials which contained the adsorbent.
This paper reports not only the outline of the half-cell potential correction procedure and the SSI method but also the effectiveness of those methods as shown through trial repair work to actual concrete railway structures.

\section{Diagnosis of reinforcing bar corrosion}

\subsection{Variation of half-cell potential and correction procedure}

The half-cell potential of a reinforcing bar is mainly affected by several factors such as water content, neutralization depth and salt content of the cover concrete.

Measurements of the half-cell potential have been performed at the concrete surface and near the reinforcing bar in order to evaluate quantitatively the effects of the water content (in the following, water content means the value at the concrete surface if not otherwise specified) and the neutralization depth (referred to as "carbonation depth" in the following). Specimens of $100 \times 100 \times 400 \mathrm{~mm}$ were prepared with $300 \mathrm{~kg} / \mathrm{m}^{3}$ cement in volume and $65 \%$ water-cement ratio, assuming that the corrosion by salt injury had a tendency to proceed easily when the water content was high. Each specimen contained a reinforcing bar of $\phi 13 \times 220 \mathrm{~mm}$ with cover concrete of 40 to $45 \mathrm{~mm}$ thickness and a buried reference electrode as shown in Fig.1. A certain amount of sodium chloride was added into the mixing water to make the $\mathrm{Cl}$ content in the concrete specimen $1 \%$. The specimens were demolded the following day, then cured in water for seven days.

The relationship between the water content and the half-cell potential was investigated first. Specimens having various water contents were prepared by drying them in the air for different periods. The water content was measured by means of a high frequency capacity moisture meter and the half-cell potentials by means of a ref- 
erence electrode and a high impedance potentiometer.

After the measurements, in order to investigate the effect of carbonation on the half-cell potential, the specimens were subjected to accelerated carbonation with 20 $\%$ carbon dioxide concentration at $30{ }^{\circ} \mathrm{C}$ and $40 \% \mathrm{RH}$ for specified periods. Then the relationship among the water content, the carbonation depth and the half-cell potential was examined. The carbonation depth was measured on a cut section surface by the phenolphthalein method.

(1) Relationship between the water content and the halfcell potential

Fig. 2 shows the relationship between the water content and the half-cell potential near the reinforcing bar (E1) and at the concrete surface (E2). The values of E1 varied in the range between -270 and $-320 \mathrm{mV}$ (vs. CSE), becoming slightly nobler with the decrease of water content. It is well known that a normal reinforcing bar covered with passive film shows a value about -150 to $-160 \mathrm{mV}$ of the half-cell potential. Based on this fact, the insufficient formation of the passive film because of the presence of $\mathrm{Cl}^{-}$is considered to be the main reason why the half-cell potential showed such less noble values.

On the other hand, the value of E2 became nobler rapidly with the decrease of the water content. As shown in Fig.2, the difference between E1 and E2 widening with the decrease of the water content, suggests that a correction was needed for the half-cell potential when it was measured through the cover concrete. Based on these re-

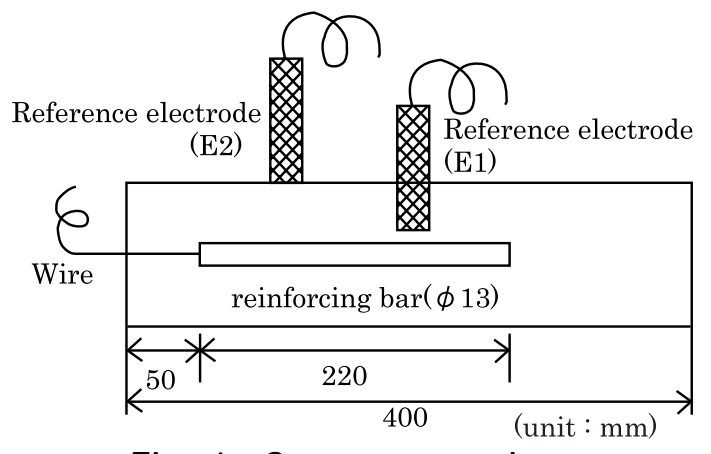

Fig. 1 Concrete specimen

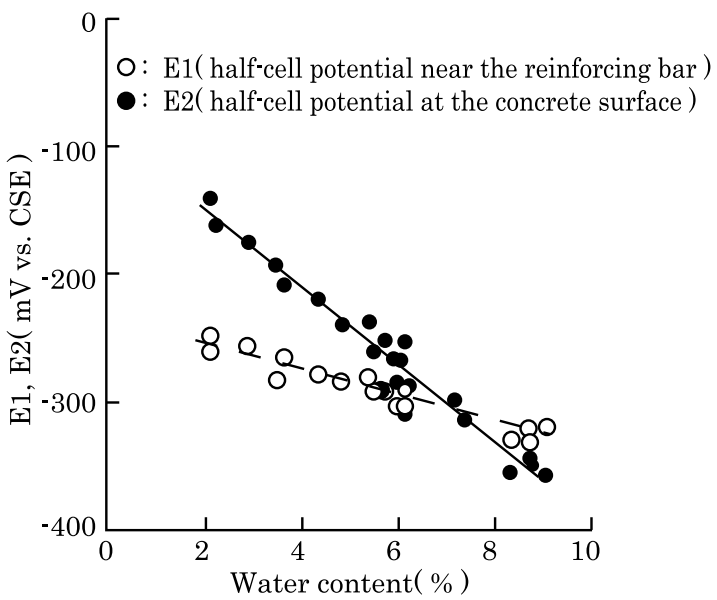

Fig. 2 Relationship between water content and half-cell potential sults, the difference between E1 and E2 was attributed to the difference in the water content at the surface and inside of the concrete.

The difference between E1 and E2 caused by the variation of the water content could be approximated with the equation,

$$
\mathrm{Z}(\mathrm{mV})=-20 \cdot \mathrm{X}(\%)+140
$$

where $\mathrm{Z}$ is the deviation in the half-cell potential and $\mathrm{X}$ is the water content.

In the results of this investigation, $\mathrm{E} 1$ was equal to $\mathrm{E} 2$ when the water content $\mathrm{X}$ is $7 \%$, while $\mathrm{E} 2$ was nobler than $\mathrm{E} 1$ when $\mathrm{X}$ was lower than that value, and less noble when $\mathrm{X}$ was higher. An experimental error caused by the reproducibility of the reference electrode including the effect of electrical connections and temperature coefficient was estimated at about $\pm 15 \mathrm{mV}$. These results showed that $\mathrm{E} 1$ was almost equal to $\mathrm{E} 2$ without any correction in the range of the water content from 6 to $8 \%$.

(2) Relationship between the carbonation depth and the

half-cell potential

Fig. 3 shows the relationship between the carbonation depth and the half-cell potential E1 and E2. E1 was almost unchanged at about $-250 \mathrm{mV}$ at various carbonation depths. It was considered from the results that the passivating reaction had achieved the equilibrium.

Because the water content varied with the progress of carbonation, measured E2 had to be corrected based on the equation (1) for the following investigation. Another correction for E2 was also needed in the case of carbonation since E2 became nobler when the carbonation proceeded further. The carbonation zone had a different $\mathrm{pH}$ value from the rest of the cover concrete. This inhomogeneity was considered to be the cause of the variation of the half-cell potential.

The difference between E1 and E2 caused by the variation of the carbonation depth could be approximated with the equation,

$$
\mathrm{Z}(\mathrm{mV})=4 \mathrm{Y}(\mathrm{mm})
$$

where $\mathrm{Z}$ is the deviation of the half-cell potential and $\mathrm{Y}$ is

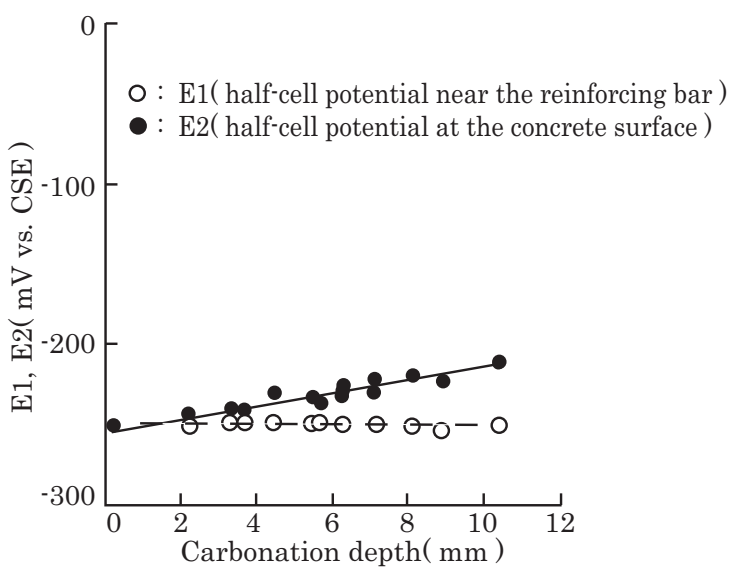

Fig. 3 Relationship between carbonation depth and half-cell potential 
the carbonation depth. Additional measurements were made with a carbonated specimen which was immersed in water to increase the water content up to 6 to $8 \%$. It was shown that if the water content was kept at 6 to $8 \%$ no correction was needed for the half-cell potential even though the carbonation proceeded in the specimen.

\subsection{Judgement of reinforcing bar corrosion using large specimen}

A large specimen, shown in Fig. 4 , of $500 \times 500 \times 1,000 \mathrm{~mm}$ was prepared to simulate a real column of a reinforced concrete structure. An investigation was conducted using the specimen to reveal the relationship between the reinforcing bar corrosion and the half-cell potential corrected suitably with equations (1) and (2).

The specimen was exposed in the atmosphere at a sunny area at the Railway Technical Research Institute for a certain period, then the half-cell potentials were measured. The results were compared with the results of the direct observation in order to evaluate the reliability of diagnosis based on the half-cell potential. A thinner cover concrete with a thickness of $25 \mathrm{~mm}$ was adopted to accelerate the reinforcing bar corrosion during the exposure in the atmosphere.

To observe the corrosion state of the reinforcing bar, an area about $0.25 \mathrm{~m}^{2}$ was selected at the upper part of a surface on which some cracks had developed along the main reinforcing bar. At first, the water content and the carbonation depth were measured for the correction of the half-cell potential. Then, the half-cell potential itself was measured after spraying water on the surface to mini-

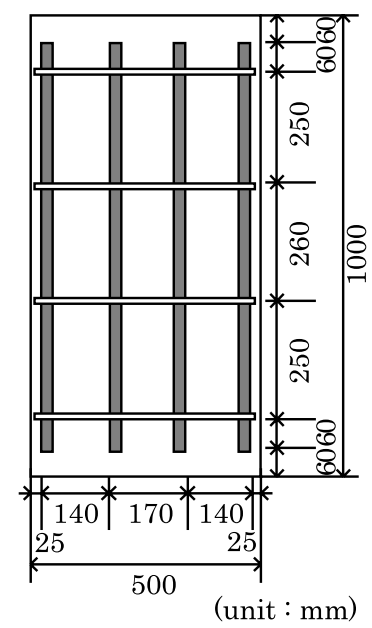

Fig. 4 Arrangement of reinforcing bar in a large specimen

\section{Table 1 Criteria of reinforcing bar corrosion}

\begin{tabular}{|c|l|}
\hline \multicolumn{2}{|c|}{ Degree of reinforcing bar corrosion } \\
\hline I & No corrosion \\
\hline II & Slight spot rust on the surface \\
\hline III & $\begin{array}{l}\text { Slightly lifted rust on the surface and } \\
\text { rust adhered to the concrete }\end{array}$ \\
\hline $\begin{array}{c}\text { IV } \\
\text { or over }\end{array}$ & $\begin{array}{l}\text { Expansive rust and partial deficit, or } \\
\text { more deteriorated }\end{array}$ \\
\hline
\end{tabular}

mize the contact resistance.

The half-cell potential without correction and the diagnosis based on the ASTM judgement criteria ${ }^{7)}$ were compared. The half-cell potential less noble than $-350 \mathrm{mV}$ indicated that the reinforcing bar is corroded with more than $90 \%$ of possibility, and that range of values was detected only at the center and cracked part, while it was -200 to $-350 \mathrm{mV}$ at other parts being judged as "corrosion state is indeterminate". However, a direct observation of the reinforcing bar after cover concrete was chipped off showed that much more was corroded than estimated above. The degree of corrosion of the reinforcing bar was from II to IV according to other criteria in Table 1 . The above criteria were proposed in the project "Technological Development for Evaluation of Durability of Concrete Structures" which is a comprehensive technological development project by the Ministry of Construction. Fig. 5 (a) shows the results of the direct observation of reinforcing bar corrosion labeled according to the criteria. This shows that the diagnosis based on the ASTM criteria could not reproduce the actual corrosion state.

In the next step, the correction of the half-cell potential for both the water content and the carbonation depth were applied using equations (1) and (2) because the water content was 4.0 to $4.8 \%$ and the carbonation depth was 6 to $8 \mathrm{~mm}$ in the specimen. Fig. 5 (b) shows the distribution of the corrected half-cell potential labeled according to the following three ranges.
1) $-250 \mathrm{mV} \geqq \mathrm{E}>-350 \mathrm{mV}$
2) $-350 \mathrm{mV} \geqq \mathrm{E}>-450 \mathrm{mV}$
3) $-450 \mathrm{mV} \geqq \mathrm{E}$

A comparison of the distribution with the result of direct observation indicated that the reinforcing bar was

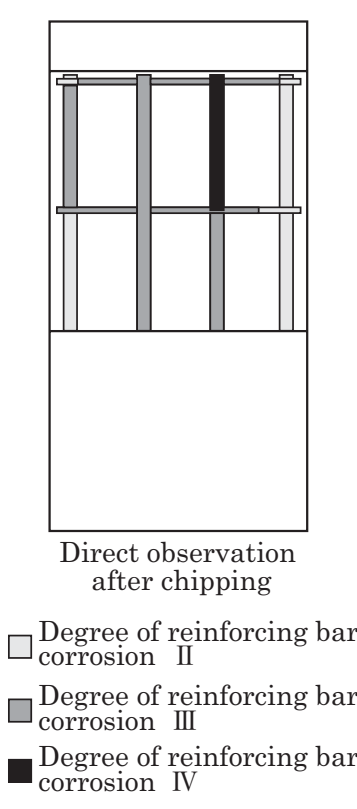

(a)

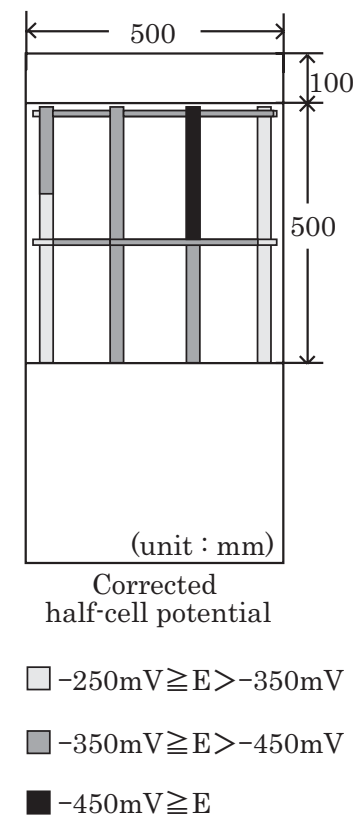

(b)
Fig. 5 Results of the investigation of reinforcing bar corrosion 
definitely corroded when the corrected half-cell potential was less noble than $-250 \mathrm{mV}$. The corrected half-cell potential of -250 to $-350 \mathrm{mV}$ could be interpreted as degree II of reinforcing bar corrosion or in the state of spot rust, while the corrected half-cell potential of -350 to $-450 \mathrm{mV}$ could be interpreted as degree III reinforcing bar corrosion or in the state of spread rust, and the corrected halfcell potential less noble than $-450 \mathrm{mV}$ could be interpreted as degree IV reinforcing bar corrosion or in the state of partial deficit. The boundary value of $-250 \mathrm{mV}$ between the degree of reinforcing bar corrosion I and II was determined based on the result obtained in paragraph 2.1, that is the half-cell potential at the condition where no corrosion occurred because of the existence of the passive film was about $-250 \mathrm{mV}$.

As a result, the relationship between the degree of reinforcing bar corrosion and the half-cell potential corrected for the water content and the carbonation depth was derived as in Table 2.

Table 2 Relationship between the corrected half-cell potential and the degree of reinforcing bar corrosion

\begin{tabular}{|c|c|}
\hline $\begin{array}{c}\text { Corrected } \\
\text { half-cell potential }\end{array}$ & $\begin{array}{c}\text { Degree of reinforcing } \\
\text { bar corrosion }\end{array}$ \\
\hline $\mathrm{E} \geqq-250 \mathrm{mV}$ & $\mathrm{I}$ \\
\hline$-250 \mathrm{mV} \geqq \mathrm{E}>-350 \mathrm{mv}$ & II \\
\hline$-350 \mathrm{mV} \geqq \mathrm{E}>-450 \mathrm{mv}$ & III \\
\hline$-450 \mathrm{mV} \geqq \mathrm{E}$ & $\mathrm{IV}$ or over \\
\hline
\end{tabular}

\subsection{Half-cell potential correction procedure and application to actual concrete structures}

Fig. 6 shows the half-cell potential correction procedure for the water content and the carbonation depth. It was not required to correct the half-cell potential when the water content was between 6 and $8 \%$ (correction value $=0$ ), but correction should be required in other conditions using equations (1) and (2). We proposed this procedure based on the corrected half-cell potential and the criteria cited in Table 2 as the half-cell potential correction procedure.

The results of applying of the procedure to some actual concrete structures such as tunnel walls, slabs and piers are summarized in Table 3. Equations (1) and (2) were used to correct the half-cell potential if needed.

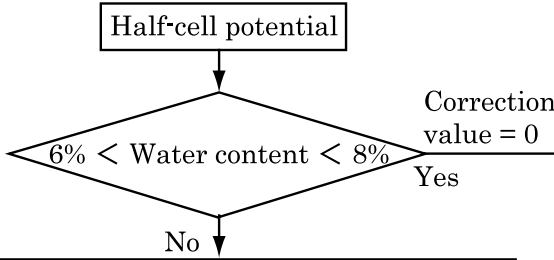

Correction for water content : Equation (1)

O Correction for carbonation depth : Equation (2)

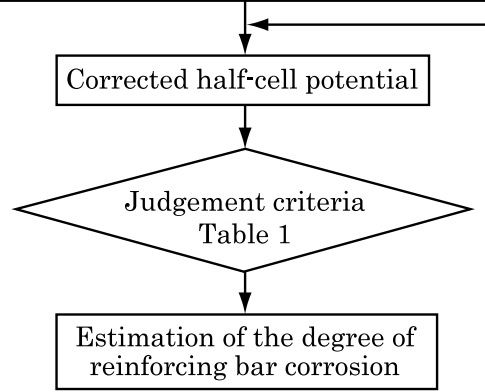

Fig. 6 Half-cell potential correction procedure

In case 1 , where the corrected half-cell potential was nobler than $-250 \mathrm{mV}$, direct observation showed that the reinforcing bar was not corroded. This result very much agrees with the judgement based on the corrected half-cell potential proposed here. In cases 2 to 6 , no changes were observed in the appearance except for minor cracks presumably due to drying shrinkage. In these cases, however, reinforcing bar corrosion was detected as degree II corrosion where the corrected half-cell potential was -250 to $-350 \mathrm{mV}$, and as degree III where it was -350 to $-450 \mathrm{mV}$. In cases 7 and 8 where both the water content and the $\mathrm{Cl}$ content were high, characteristic alteration was observed with cracks, which seemed to have been caused by reinforcing bar corrosion, running along the reinforcing bar and the surrounding concrete partly lifted. In these cases, the corrected half-cell potential was less noble than $-450 \mathrm{mV}$ suggesting that the reinforcing bar corrosion was degree IV or over and agreed with the direct observation.

Based on the above results, it was confirmed that the relationship between the corrected half-cell potential and the degree of reinforcing bar corrosion satisfactorily agreed with the conditions of actual concrete structures. Therefore, with the half-cell potential correction procedure, not only the occurrence of the corrosion, but also the degree of the corrosion can be evaluated.

Table 3 Application to actual concrete structures

\begin{tabular}{|c|c|c|c|c|c|c|c|c|c|}
\hline Case & $\begin{array}{c}\text { Concrete } \\
\text { structure }\end{array}$ & $\begin{array}{c}\text { Measured } \\
\text { half-cellpotential } \\
\text { mV }\end{array}$ & $\begin{array}{c}\text { ASTM } \\
\text { judgement }\end{array}$ & $\begin{array}{c}\text { Water } \\
\text { content(\%) }\end{array}$ & $\begin{array}{c}\text { Carbonation } \\
\text { depth(mm) }\end{array}$ & $\begin{array}{c}\text { Salt } \\
\text { content } \\
\left(\mathrm{kg} / \mathrm{m}^{3}\right)\end{array}$ & $\begin{array}{c}\text { Corrected } \\
\text { halfcellpotential } \\
\text { (mV) }\end{array}$ & $\begin{array}{c}\text { Estimated } \\
\text { degree of } \\
\text { corrosion }\end{array}$ & $\begin{array}{c}\text { Observed } \\
\text { degree of } \\
\text { corrosion }\end{array}$ \\
\hline 1 & slab & $-100 \sim-120$ & no corrosion & $4.3 \sim 4.6$ & $8 \sim 10$ & 1.0 & $-230 \sim-250$ & I & I \\
\hline 2 & pier & $-20 \sim-40$ & no corrosion & $3.0 \sim 3.2$ & $53 \sim 55$ & 3.5 & $-280 \sim-330$ & II & II \\
\hline 3 & pier & $-251 \sim-280$ & indeterminate & $4.0 \sim 4.5$ & $5 \sim 10$ & 3.0 & $-310 \sim-340$ & II & II \\
\hline 4 & pier & $-270 \sim-320$ & indeterminate & $4.0 \sim 4.5$ & $5 \sim 10$ & 3.0 & $-359 \sim-420$ & III & III \\
\hline 5 & pier & $-350 \sim-370$ & corrosion & $4.0 \sim 4.5$ & $5 \sim 10$ & 3.0 & $-430 \sim-450$ & III & III \\
\hline 6 & pier & $-230 \sim-260$ & indeterminate & $4.8 \sim 5.2$ & $20 \sim 25$ & 1.0 & $-410 \sim-440$ & III & III \\
\hline 7 & tunnel wall & $-460 \sim-490$ & corrosion & $7.1 \sim 7.8$ & $15 \sim 20$ & 10 & $-460 \sim-490$ & IV or over & IV or over \\
\hline 8 & tunnel wall & $-530 \sim-580$ & corrosion & $7.1 \sim 7.8$ & $15 \sim 20$ & 10 & $-530 \sim-580$ & IV or over & IV or over \\
\hline
\end{tabular}




\section{Suppression of reinforcing bar corrosion}

\subsection{Synthesis of chlorine ion adsorbent}

To suppress the reinforcing bar corrosion caused by salt injury, it is effective to fix and deactivate the $\mathrm{Cl}^{-}$in the concrete. Chemically synthesized nitrous type hydrocalmite is expected to behave as an anion exchanger to adsorb the $\mathrm{Cl}^{-}$. This material is referred to as "adsorbent" in the following. Fig.7 shows a schematic view of the structure of the material. A scanning electron microscopic (SEM) image of the adsorbent is given in Fig.8.

In the crystal structure of the adsorbent, a part of calcium divalent cation $\mathrm{Ca}^{2+}$ was substituted by aluminum trivalent cation $\mathrm{Al}^{3+}$ in the calcium hydroxide layer $\mathrm{Ca}(\mathrm{OH})_{2}$ importing an excess positive charge to the layer. An amount of anion had to be introduced in the interlayer space to compensate for the positive charge. As the anion species to compensate for the positive charge on the layer, $\mathrm{NO}_{2}^{-}$was chosen because of its characteristics to suppress reinforcing bar corrosion. In contact with $\mathrm{Cl}^{-}$, this material adsorbed the $\mathrm{Cl}^{-}$releasing the $\mathrm{NO}_{2}^{-}$at the same time following the ion exchange reaction (3).

$$
\begin{aligned}
& 3 \mathrm{CaO} \mathrm{Al}{ }_{2} \mathrm{O}_{3} \mathrm{Ca}\left(\mathrm{NO}_{2}\right)_{2} \mathrm{nH}_{2} \mathrm{O}+2 \mathrm{Cl}^{-} \\
& \text {(Nitrous type hydrocalmite) } \\
& \stackrel{3 \mathrm{CaO} \mathrm{Al} \mathrm{O}_{3} \mathrm{CaCl}_{2} \mathrm{nH}_{2} \mathrm{O}+2 \mathrm{NO}_{2}^{-}}{\longrightarrow}
\end{aligned}
$$

Based on both effects, that is, the removing of $\mathrm{Cl}^{-}$and the adding of $\mathrm{NO}_{2}^{-}$, it is expected to suppress the reinforcing bar corrosion very effectively.

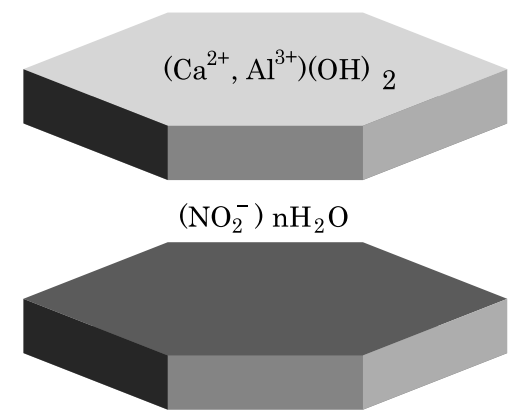

Fig. 7 Schematic structure of chlorine ion adsorbent

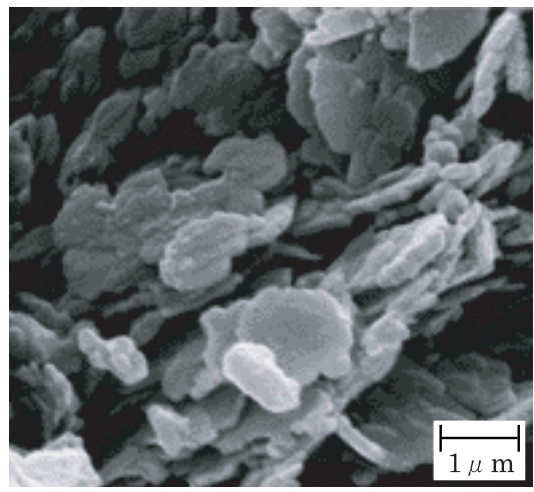

Fig. 8 Scanning electron micrograph of chlorine ion adsorbent

\subsection{Corrosion inhibiting effect examined using joined specimen}

In order to investigate the succeeding corrosion caused by salt remaining in the backside of the reinforcing bar after chipping off the cover concrete, a specimen of mortar with high salt content (referred to as "high salt mortar") joined with repairing mortar was prepared. The joined specimen, shown in Fig.9, of $40 \times 40 \times 160 \mathrm{~mm}$ was prepared as follows. The lower half was cast at first with high salt mortar of $500 \mathrm{~kg} / \mathrm{m}^{3}$ cement and $65 \%$ watercement ratio. A relatively large amount of sodium chloride was added into mixing water such as $2 \%$ (about $10 \mathrm{~kg} / \mathrm{m}^{3}$ ), $3 \%$ (about $15 \mathrm{~kg} / \mathrm{m}^{3}$ ) and $5 \%$ (about $25 \mathrm{~kg} / \mathrm{m}^{3}$ ) to accelerate the corrosion. Then a $\phi 10 \mathrm{~mm}$ steel bar was placed on the cast high salt mortar surface with the lower half of the bar buried in the mortar. Finally, repairing mortar which contained a specified amount of adsorbent was cast on them to finish the test specimen. As a reference, another specimen was also prepared using repairing mortar including no adsorbent. The cast specimens were demolded the next day and cured for 14 days with polyethylene sealing, then subjected to a cyclic dry-wet test (drying for 4 days and immersion in water for 3 days).

The corrected half-cell potential was measured at each drying period and the concentrations of $\mathrm{Cl}^{-}\left(\left[\mathrm{Cl}^{-}\right]\right)$and $\mathrm{NO}_{2}^{-}\left(\left[\mathrm{NO}_{2}^{-}\right]\right)$in the pore solution were analyzed at the 6 th cycle when the rest potential became stable. The chemical analysis was made by ion chromatography of the pore solution which was extracted with a squeezer at about $5 \mathrm{kN} / \mathrm{mm}^{2}$.

Fig.10 shows the variation of the corrected half-cell potential. It was observed for the reference specimen that, though the corrected half-cell potential was relatively noble such as $-250 \mathrm{mV}$ for the specimen with $2 \% \mathrm{Cl}$ content, the values for the specimens with 3 and $5 \% \mathrm{Cl}$ content were much less noble such as -400 to $-550 \mathrm{mV}$ after the 4 th cycle at which a corrosive environment might be produced around the reinforcing bar. In contrast, for the joined specimen containing the adsorbent, the corrected rest potential was nobler than $-250 \mathrm{mV}$ even if the $\mathrm{Cl}$ content was as high as $3 \%$ and $5 \%$. This result showed that the addition of the adsorbent could modify even the high salt mortar side to a corrosion inhibiting environment.

In order to confirm this effect, the pore solutions of both specimens with $5 \% \mathrm{Cl}$ content were analyzed for $\left[\mathrm{Cl}^{-}\right]$ and $\left[\mathrm{NO}_{2}{ }^{-}\right]$after the 6 th cycle. As shown in Fig. 11, the $\left[\mathrm{Cl}^{-}\right]$in the pore solution of the high salt mortar of the test specimen was less than half that of the reference specimen. This fact showed that the $\mathrm{Cl}^{-}$in the backside of the reinforcing bar had effectively been removed. The

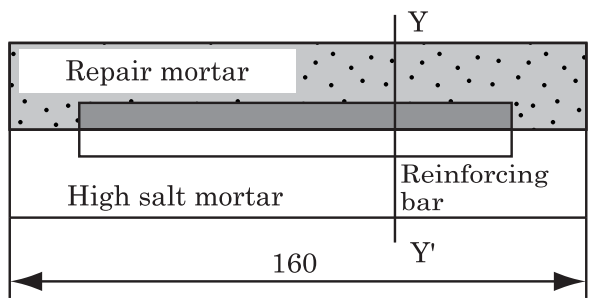

(unit : $\mathrm{mm}$ )

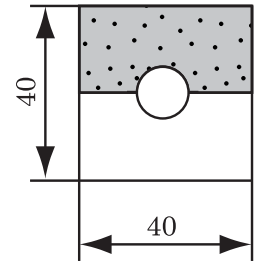

Y-Y'section
Fig. 9 Joined specimen 


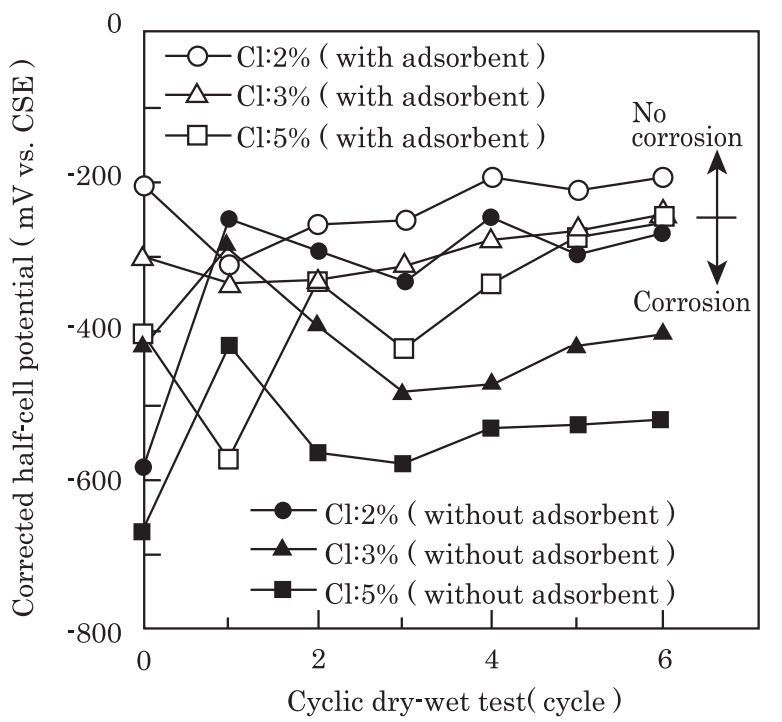

Fig. 10 Variation of the corrected half-cell potential

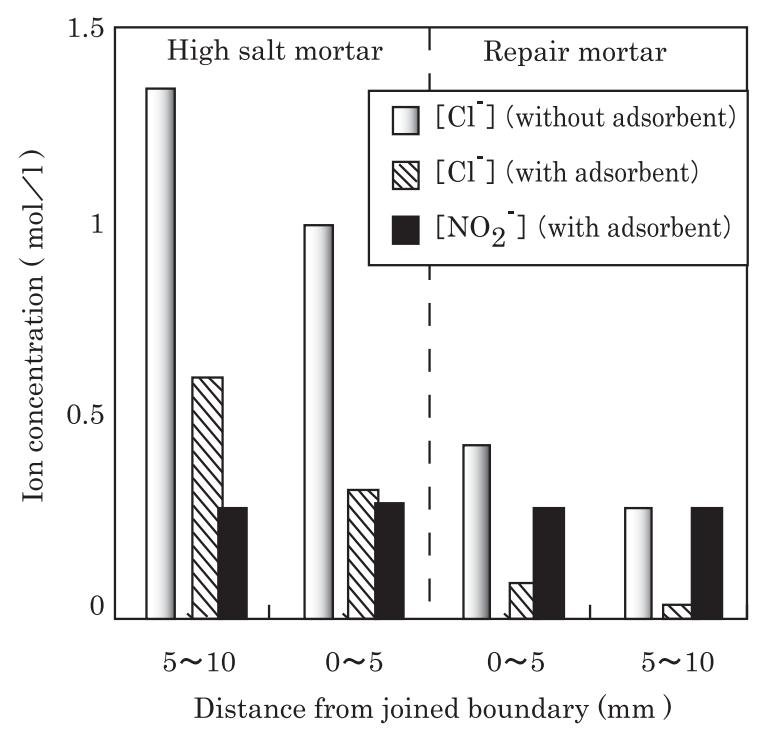

Fig. $11\left[\mathrm{Cl}^{-}\right]$and $\left[\mathrm{NO}_{2}^{-}\right]$in the pore solution

test specimen also indicated that the released $\mathrm{NO}_{2}^{-}$had spread even into the high salt mortar side. In this case, $\left[\mathrm{NO}_{2}{ }^{-}\right] /\left[\mathrm{Cl}^{-}\right]$ratio was 0.9 at the backside of the reinforcing bar. It is generally said that a corrosion inhibiting environment is maintained when the ratio is 0.6 to $1.0^{8)}$. On the basis of this fact, a high corrosion inhibiting effect of the repairing mortar containing the adsorbent was confirmed.

\section{Suppressing salt injury method and an example of repair work}

\subsection{Repairing materials and suppressing salt injury}

Based on the results mentioned above, two repairing materials were prepared. One was a paste (referred to as "corrosion inhibiting paste") which was applied directly on the reinforcing bar surface. The other was a mortar (referred to as "corrosion inhibiting mortar") which was ap-

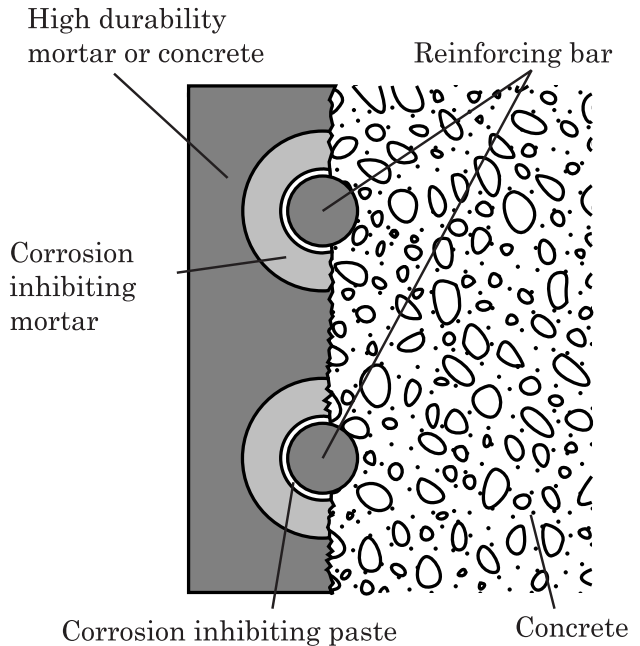

Fig. 12 Concept of SSI method

plied outside of the paste to protect it. Both materials contained the adsorbent with adsorbent-cement ratio at $2: 8$ in weight. A type of emulsion was added to both repairing materials to improve their workability. Measurements of compressive strength and other properties, following the standard procedures described in JIS, showed that the corrosion inhibiting paste and mortar were properly prepared as repairing materials.

A repairing method characterized by these materials was developed as the Suppressing Salt Injury method (SSI method shown in Fig.12). This method consists of the following steps. At first, the cover concrete is chipped off until the position of the reinforcing bar, then the rust on the surface of the reinforcing bar is removed sufficiently. In the next step, the corrosion inhibiting paste is plastered on the surface of the reinforcing bar to a thickness of about $1 \mathrm{~mm}$, then the corrosion inhibiting mortar is mounted to cover the paste until a thickness of 15 to $20 \mathrm{~mm}$. In the final step, high durability mortar or concrete is cast to finish the surface. This method not only replaces low durability concrete with high durability mortar or concrete, but also suppresses the reinforcing bar corrosion by the reduction of $\mathrm{Cl}^{-}$in the backside of the reinforcing bar and the addition of $\mathrm{NO}_{2}^{-}$.

\subsection{Example of repair work}

\section{(1) Outline of objective structure}

As an example of repair work on an actual structure, concrete abutment of a railway station platform constructed in 1973 was selected. The structure could be affected by the leakage containing salt from deicing chemicals (calcium chloride).

To survey the deterioration of the structure, measurement of the half-cell potential was performed at nine points on the concrete surface shown in Fig.13.

Fig.14 shows the corrected half-cell potential using half-cell potential correction procedure for the water content and the carbonation depth. The corrected half-cell potential was -310 to $-340 \mathrm{mV}$ at the inside point No.1 and No.2, -350 to $-390 \mathrm{mV}$ at the points No.3 to No.8, and -420 to $-430 \mathrm{mV}$ at the point No. 9 at the end of the abutment. The measurement indicated that corrected 


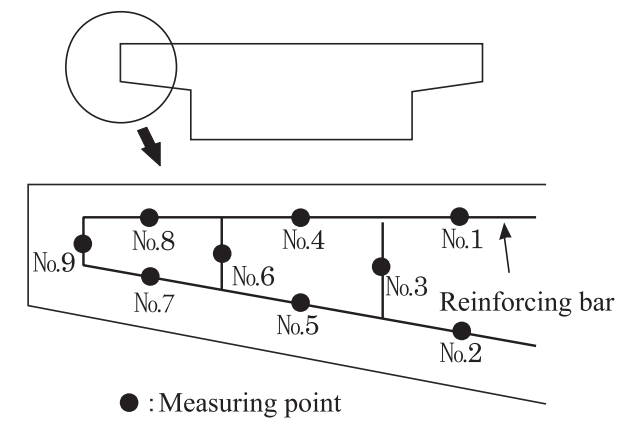

Fig. 13 Concrete abutment

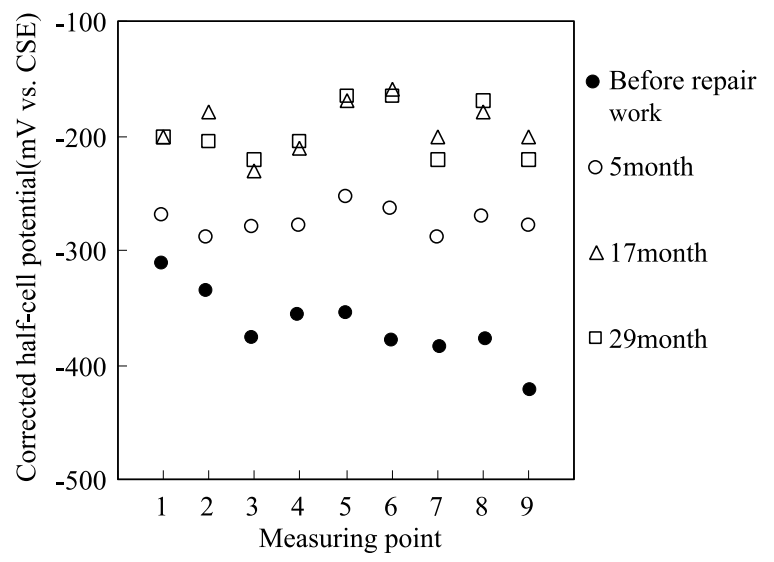

Fig. 14 Variation of corrected half-cell potential

half-cell potential was the lowest at the end of the abutment and became slightly higher inside.

Based on the results mentioned above, it was found that the reinforcing bars were more corroded at the end of the abutment than at other positions. It was considered that the calcium chloride spread on the platform had penetrated inside from the end of the abutment to supply chloride ions to the concrete.

(2) Repair work of SSI method and follow-up inspection

After chipping off the cover concrete and removing rust out of the reinforcing bar, the SSI method was applied. The repair process described in the paragraph 4.1 was followed, and high durability mortar that contained silica fume was adopted in the finishing step. After repairing, the corrected half-cell potential was measured to discuss the effect of SSI method.

The variations of the corrected half-cell potential are shown in Fig. 14. In the 5th month, the corrected half-cell potential became -200 to $-300 \mathrm{mV}$ nobler than those before the repair work. In the 17 th and 29 th month, they shifted further to nobler side beyond $-250 \mathrm{mV}$, showing that the high corrosion inhibiting effect was maintained.

\section{Conclusion}

In this study, a systematic diagnosis and repair procedure for the reinforcing bar corrosion was developed through the laboratory experiments and the repair work to an actual concrete structure, and the following results were obtained.

First, empirical equations to correct the half-cell potential for the water content and the carbonation depth of the cover concrete were derived. Based on the equations, a half-cell potential correction procedure was proposed to judge not only the occurrence of the corrosion but also the degree of corrosion. The validity of this procedure was verified by applying it to actual concrete structures.

Second, chlorine ion adsorbent was chemically synthesized which adsorbed $\mathrm{Cl}^{-}$in concrete and released $\mathrm{NO}_{2}^{-}$. The Suppressing Salt Injury method, named SSI method, was developed using cement-base corrosion inhibiting materials added with the adsorbent. The method was applied to an actual concrete railway structure. The structure which was repaired by the SSI method has maintained sound condition so far.

\section{Acknowledgement}

The authors wish to extend sincere thanks to the Maintenance Division of the Highway Public Corporation Research Institute, for their joint research of the repair system, and to the Maintenance Divisions of East Japan Railway Company and West Japan Railway Company for permitting to perform trial repair work to actual concrete structures. Special thanks also to Dr. K. Iwafuchi, Materials Technology Division of the Railway Technical Research Institute for his assistance in completing this paper.

\section{References}

1) T.Kobayashi, T. Yonezawa and K. Shutto: "The diagnosis of reinforcing-bar corrosion(in Japanese)," Morikita Shuppan Co. LTD.,1993

2) R.T.L. Allen, S.C. Edwards and J.D.N. Shaw: "The Repair of Concrete Structures," Second edition, Chapman \& Hall Inc., 1993

3) Browne, R.D: "Mechanisms of Corrosion of Steel in Concrete in Relation to Design, Inspection and Repair of Offshore and Coastal Structure, "ACI SP-65, 1980

4) Dawson, J.L.: "Corrosion Monitoring of Steel in Concrete", Crane, A.P. ed., "Corrosion of Reinforcement in Concrete Construction," Ellis Horwood Ltd., p.175, 1983

5) Mckenzie,S.G.: "Techniques for Monitoring Corrosion of Steel in Concrete," Corrosion Prevention \& Control,Vol.34, No.1, p.11, 1987

6) Figg, J.W. and Marsden, A.F.: "Development of Inspection Techniques for Reinforced Concrete," Offshore Technology Report, OTH84205, 1987

7) ASTM C876 "Standard Test Method for Half Cell Potantials of Reinforcing Steel in Concrete," 1980

8) A.M. Rosenberg, et al.: "The Inhibition of ChlorideInduced Corrosion in Reinforced Concrete by Calcium Nitrate," American Society for Testing and Materials, 1980 